\title{
Temporal variations and bioaccumulation of heavy metals in different Suaeda salsa marshes of the Yellow River estuary, China
}

\author{
Hongli Song • Zhigao Sun
}

Received: 19 March 2014 / Accepted: 12 June 2014 / Published online: 25 July 2014

(C) Springer-Verlag Berlin Heidelberg 2014

\begin{abstract}
To understand the temporal variations and bioaccumulation of heavy metals in the coastal marshes, the concentrations of heavy metals $(\mathrm{Cr}, \mathrm{Ni}, \mathrm{Pb}$, and $\mathrm{Cu})$ in the two Suaeda salsa marshes [middle S. salsa marsh (MM) and low $S$. salsa marsh (LM)] of the Yellow River estuary were determined from May to November in 2008 by in situ sampling and inductively coupled plasma mass spectrometry (ICP-MS) analysis. Results showed that heavy metal concentrations in S. salsa of MM and LM were generally in the order of $\mathrm{Cu}>\mathrm{Cr}>\mathrm{Pb}>\mathrm{Ni}$, while those in sediments fell in the order of $\mathrm{Cr}>\mathrm{Ni}>\mathrm{Cu}>\mathrm{Pb}$. Heavy metal concentrations of $S$. salsa in MM and LM were different, and significant differences were observed in stems $(F=4.797, p=$ $0.046)$ and litters $(F=6.799, p=0.026)$ for Ni. Litter was the main stock of heavy metals, and the allocations of $\mathrm{Cr}$, $\mathrm{Ni}$, and $\mathrm{Pb}$ reached 31.25-51.31, 28.49-42.58, and 29.55$66.79 \%$ (in MM) and 36.73-48.60, 41.70-57.87, and $33.30-60.64 \%$ (in LM), respectively. The ratios of roots/ leaves $(\mathrm{R} / \mathrm{L})$ and roots/stems $(\mathrm{R} / \mathrm{S})$ for $\mathrm{Cr}$ and $\mathrm{Ni}$ in $\mathrm{MM}$ were mostly greater than 1 , while those ratios in LM were mostly less than 1 , indicating that $\mathrm{Cr}$ and $\mathrm{Ni}$ in $S$. salsa at LM had greater mobility compared with those at MM. Moreover, the [accumulation factor, $\mathrm{AF}]_{\text {plant }}$ of $\mathrm{Cr}, \mathrm{Ni}$, $\mathrm{Cu}$, and $\mathrm{Pb}$ in $\mathrm{LM}$, especially $[\mathrm{AF}]_{\text {root }}$ and $[\mathrm{AF}]_{\text {stem }}$ of $\mathrm{Cr}$ and $[\mathrm{AF}]_{\text {litter }}$ of $\mathrm{Ni}$, was also higher than that in MM. These
\end{abstract}

Responsible editor: Stuart Simpson

H. Song $\cdot$ Z. Sun $(\bowtie)$

Key Laboratory of Coastal Environmental Processes and Ecological Remediation, Yantai Institute of Coastal Zone Research, Chinese Academy of Sciences, Yantai, Shandong 264003, People's Republic of China

e-mail: zgsun@yic.ac.cn

H. Song

University of Chinese Academy of Sciences, Beijing 100049,

People's Republic of China indicated that $S$. salsa grown in LM was more suitable for potential biomonitor or phytoremediation of $\mathrm{Cr}, \mathrm{Ni}, \mathrm{Cu}$, and $\mathrm{Pb}$ if intertidal sediments were seriously contaminated with an increase of pollutant loading (especially heavy metals) in the Yellow River estuary. The use of biomonitor ( $S$. salsa) living and growing in LM could yield valuable information not only on the presence of anthropogenic stressors, but, more importantly, on the adverse influence the stressors are having on the environment.

Keywords Heavy metals $\cdot$ Suaeda salsa $\cdot$ Sediment . Temporal variation $\cdot$ Yellow River estuary

\section{Introduction}

Pollution of the natural environment by heavy metals is a worldwide problem (Irabien and Velasco 1999). Estuaries are zones of complex interaction between fluvial and marine processes that may act as a geochemical trap for heavy metals bonded in the sediments, and the mixing of continental river water and marine salt water usually leads to flocculation and accumulation processes of heavy metals (Flegal et al. 1991; Moran et al. 1996). With the rapid industrialization and economic development in coastal zone, large amounts of heavy metals are continuing to be imported to estuary through rivers, runoff, and land-based point sources (Zhang et al. 2007). Estuaries have been recognized as a major transport path for metals of natural and anthropogenic origins from the continent to the coastal waters (Masson et al. 2006). The pollution problem in estuaries is characterized by interconnected, complicated interactions, often making the interpretation of the disturbance effects in such ecosystems complex and confusing (Dauvin 2008). Coastal marshes are the main sinks for heavy metals (Williams et al. 1994). Various hydrological processes and sediment physicochemical properties significantly 
influence the biochemical processes of heavy metals in marshes. There has been intensely increasing interest in understanding the pollution of heavy metals in coastal marsh due to the great influences of human activities ( $\mathrm{Li}$ et al. 2000, 2007; Caeiro et al. 2005; Abrahim and Parker 2008; Bai et al. 2011, 2012; Xiao et al. 2013). Exploring heavy metal accumulation in plants for the remediation (or phytoremediation) of coastal environment is of great significance (Chaney et al. 1997; Deng et al. 2004).

The Yellow River is well known as a sediment-laden river. Approximately $1.05 \times 10^{7}$ tons of sediment was carried to the estuary every year (Cui et al. 2009) and deposited in the estuary, resulting in vast floodplain and special marsh landscape (Xu et al. 2002). Meanwhile, approximately $4.40 \times 10^{5}$ tons of pollutants from the cities and industrial and mining enterprises in the Yellow River basin were discharged into Bohai Sea by the Yellow River in 2012, including $1.11 \times 10^{3}$ tons of heavy metals which increased by 59.5 and $73.4 \%$ compared to 2010 and 2011, respectively (State Oceanic Administration of China 2011, 2012, 2013). Since sediment deposition is an important process in the formation and development of coastal marshes in the Yellow River estuary, large amounts of heavy metals contained in sediments may have significantly toxic effects on the wildlife in coastal marshes (Zhang et al. 2010). Thus, understanding the distribution and geochemical behavior of heavy metals in coastal marshes of the Yellow River estuary will be of significance.

Phytoremediation has been widely applied to reduce, remove, degrade, or immobilize environmental toxins. Categories of phytoremediation include phytoextraction, phytovolatilization, rhizofiltration, and phytostabilization (Chaney et al. 1997). The effectiveness of a phytoremediation system depends on the selection of appropriate plants for the particular environment. Information on the accumulation properties of plants is very useful in choosing appropriate plants for marsh phytoremediation systems (Duman et al. 2007). There are several attributes ascribed to the ideal candidate plant species for phytoremediation of metals, and the most important one is that plants should have sufficient capacity to tolerate the site conditions and accumulate multiple metal contaminants. Since the salinity in sediment of coastal marshes in the Yellow River estuary is very high $(>8 \mathrm{~g} / \mathrm{kg})$, the plants that are used for phytoremediation should have high saline-alkali tolerance (Guan et al. 2001; Song et al. 2012). Actually, many halophytes, such as Suaeda salsa and Tamarix chinensis, are widely distributed in intertidal zone of the Yellow River estuary, and this provides the possibility for phytoremediation of heavy metals. S. salsa is one of the most prevalent halophytes in intertidal zone, which has been widely applied for restoration of degraded salt marsh (Liu et al. 2011). As a pioneer plant, it has strong adaptations to environmental stresses, such as high salinity and seawater inundation (Han et al. 2005). Two phenotypes are generally formed in $S$. salsa distribution area due to differences of water and salinity gradients. In the middle marsh, $S$. salsa is unfrequently and irregularly affected by the tide, so the salinity of sediment is low (electrical conductivity (EC), $5.58 \pm 2.80 \mathrm{mS} \mathrm{cm}^{-1}$ ), the leaf and stem of $S$. salsa are green, and the plant is tall. In the low marsh, $S$. salsa is frequently affected by the tide; thus, the salinity of sediment is very high (EC, $18.07 \pm 0.43 \mathrm{mS} \mathrm{cm}^{-1}$ ), the leaf and stem of $S$. sals $a$ are red-violet, and the plant is very short (Wang et al. 2006). Presently, studies on nutrient variations (N, S, K, Ca, and Mg) (Mou et al. 2010a, b; Sun et al. 2010) and nutrient biological cycles (N, P, and S) (Mou et al. 2011; Sun et al. 2013a, b) of the two S. salsa marshes have been widely reported. However, information on temporal variations and bioaccumulation of heavy metals in different S. salsa marshes is very limited, and the feasibility of applying $S$. salsa to remedy polluted marsh is scarcely discussed. Considering the increase of heavy metal pollutants in the Yellow River estuary, whether $S$. salsa can be used as biomonitor of heavy metals or applied for phytoremediation in the future deserves to be studied.

In this paper, the variations, allocations, and bioaccumulations of heavy metals $(\mathrm{Cr}, \mathrm{Ni}, \mathrm{Cu}$, and $\mathrm{Pb})$ in different $S$. salsa marshes of the Yellow River estuary were comparatively studied. The objectives of this paper were (i) to study the variations of heavy metals in plant and sediment during the growing season; (ii) to explore the transfers, allocations, and bioaccumulations of heavy metals in different plants; and (iii) to evaluate the suitability of $S$. salsa as biomonitor or phytoremediation of heavy metal contamination.

\section{Materials and methods}

\section{Study region}

The study was conducted at two typical experimental plots $(500 \mathrm{~m} \times 500 \mathrm{~m})$ in the $S$. salsa distribution area [middle S. salsa marsh (MM), $37^{\circ} 45^{\prime} 57.0^{\prime \prime} \mathrm{N}, 119^{\circ}$ $09^{\prime} 40.7^{\prime \prime}$ E; low $S$. salsa marsh (LM), $37^{\circ} 46^{\prime} 38.9^{\prime \prime} \mathrm{N}$, $11909^{\prime} 41.4^{\prime \prime}$ E] in the intertidal zone of the Yellow River estuary (Fig. 1), which is located in the Nature Reserve of Yellow River Delta $\left(37^{\circ} 35^{\prime} \mathrm{N} \sim 38^{\circ} 12^{\prime} \mathrm{N}\right.$, $118^{\circ} 33^{\prime} \mathrm{E} \sim 119^{\circ} 20^{\prime} \mathrm{E}$ ) in Dongying City, Shandong Province, China. The Nature Reserve is of typical continental monsoon climate with distinctive seasons. The average temperatures in spring, summer, autumn, and winter are $10.7,27.3,13.1$, and $-5.2{ }^{\circ} \mathrm{C}$, respectively. The tide in the intertidal zone of the Yellow River estuary is irregular semidiurnal tide and the mean tidal range is $0.73 \sim 1.77 \mathrm{~m}$ ( $\mathrm{Li}$ et al. 1991). The soils are dominated by intrazonal tide soil and salt soil (Tian et al. 2005) and the main vegetations include $S$. salsa, 


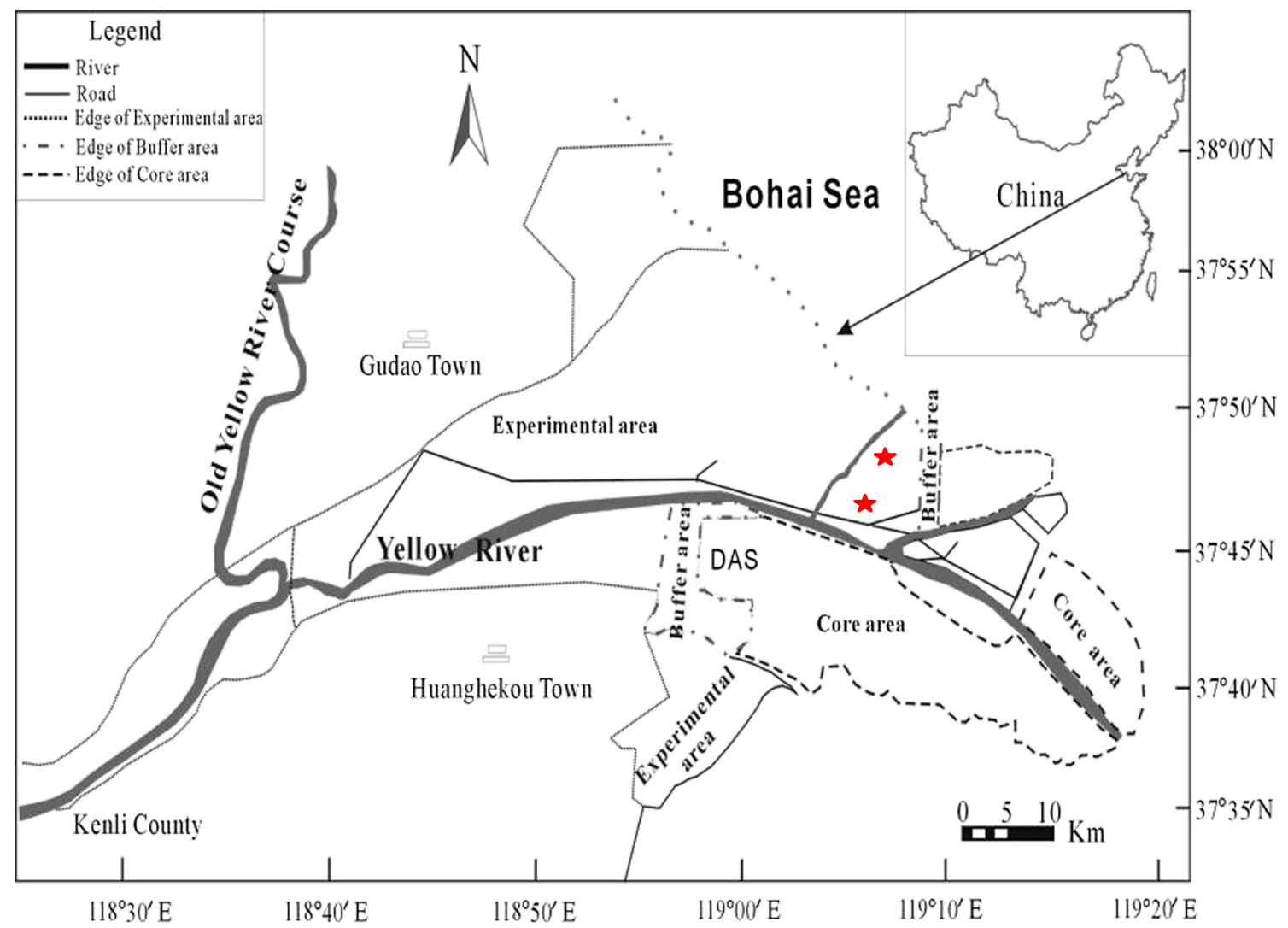

Fig. 1 Sketch of the Yellow River estuary and experimental plots (stars)

Phragmites australis, Triarrhena sacchariflora, T. chinensis, and Limoninum sinense. The sequence of geomorphic units is complete in the intertidal zone of the Yellow River estuary due to the protection of the Nature Reserve, which generally comprises three areas in a seaward direction: high marsh (HM), middle marsh (MM), and low marsh (LM). S. salsa, distributed widely in MM and LM, generally germinates in late April, blooms in July, matures in late September, and completely dies in late November. The comparison of physical and chemical properties of topsoil in MM and LM is shown in Table 1.

Study methods

\section{Sample collection}

From May to November in 2008, litter production, aboveground biomass, and belowground biomass were determined using the quadrat method $(50 \mathrm{~cm} \times 50 \mathrm{~cm})$ at the two experimental plots, with a sampling frequency of 20 days. In each experimental plot, five replications were randomly selected at a spatial scale in order to provide comprehensive information of each plot. On the sampling dates, the aboveground part of the plant was clipped near the ground, and stem, leaf, and standing dead litter were separated immediately in the laboratory. The new litter distributed in the quadrat was also collected. Roots in the quadrat were dug out and washed carefully. All plant samples were washed thoroughly with deionized water and then oven-dried at $80{ }^{\circ} \mathrm{C}$ for $48 \mathrm{~h}$. After the measurement of dry weights, the samples were ground into a fine powder $(<0.25 \mathrm{~mm})$. Since the substantial root of $S$. salsa was mostly in the upper $15 \mathrm{~cm}$ and most of the heavy metal transfers between sediment and plant occurred in the upper zone, the heavy metal concentrations in topsoil $(0-15 \mathrm{~cm})$ were studied. Sediment samples were collected per month (three replications) and bulk densities were determined simultaneously. All sediment samples were air-dried, ground and sieved through a 100-mesh nylon sieve, and kept in a precleaned container for use.

\section{Sample analysis}

A 0.1000 -g homogenized plant and soil subsample was digested with $2 \mathrm{~mL} \mathrm{HNO}_{3}, 1 \mathrm{~mL} \mathrm{HClO}_{4}$, and $5 \mathrm{~mL} \mathrm{HF}$ at $160 \sim 190^{\circ} \mathrm{C}$ for $16 \mathrm{~h}$. The residue was dissolved in $2 \mathrm{~mL}$ of 4 $\mathrm{mol} / \mathrm{L} \mathrm{HCl}$ and then diluted to $10 \mathrm{~mL}$ with deionized water for heavy metal analysis. A 0.2000 -g plant subsample was digested in a mixture of $65 \% \mathrm{HNO}_{3}(2 \mathrm{~mL})$ and $30 \% \mathrm{H}_{2} \mathrm{O}_{2}$ $(1 \mathrm{~mL})$. The residue was diluted with deionized water to 


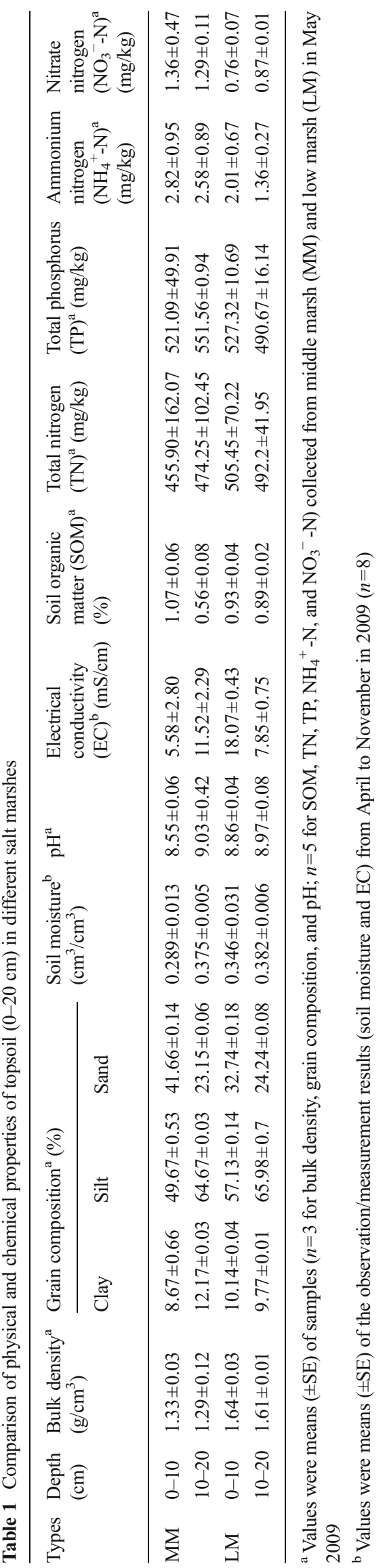

$10 \mathrm{~mL}$ for analyzing heavy metal concentrations. The concentrations of heavy metals $(\mathrm{Cr}, \mathrm{Ni}, \mathrm{Cu}$, and $\mathrm{Pb})$ in all samples were determined by inductively coupled plasma mass spectrometry (Agilent 7500 ICP-MS). Quality assurance and quality control were assessed using duplicates, method blanks, and standard reference materials (GBW07401 and GBW08513) from the National Research Center for Standards in China with each batch of samples (one blank and one standard for each of the 20 samples).

\section{Calculations}

Accumulation factor $[\mathrm{AF}]$ in relation to the heavy mental concentrations in sediment was calculated by the ratio $[\text { Element }]_{\text {plant }}$ and [Element $]_{\text {sediment }}$ (Duman et al. 2007) [Eq. (1)]:

$[\mathrm{AF}]_{\text {root }}=C_{\text {root }} / C_{\text {sediment }}$
$[\mathrm{AF}]_{\text {stem }}=C_{\text {stem }} / C_{\text {sediment }}$
$[\mathrm{AF}]_{\text {leaf }}=C_{\text {leaf }} / C_{\text {sediment }}$
$[\mathrm{AF}]_{\text {litter }}=C_{\text {litter }} / C_{\text {sediment }}$

where $C_{\text {root }}, C_{\text {stem }}, C_{\text {leaf }}, C_{\text {litter }}$ and $C_{\text {sediment }}$ were the average heavy metal concentrations in root, stem, leaf, litter, and sediment over all sampling period, respectively.

The metal concentration quotient for roots/stems $(\mathrm{R} / \mathrm{S})$, roots/leaves $(\mathrm{R} / \mathrm{L})$, and stems/leaves $(\mathrm{S} / \mathrm{L})$ was calculated according to Dahmani-Muller et al. (2000) [Eq. (2)]:

$$
\begin{aligned}
& \mathrm{R} / \mathrm{S}=C_{\text {root }} / C_{\text {stem }} \\
& \mathrm{R} / \mathrm{L}=C_{\text {root }} / C_{\text {leaf }} \\
& \mathrm{S} / \mathrm{L}=C_{\text {steam }} / C_{\text {leaf }}
\end{aligned}
$$

Heavy metal stocks in plant compartments $\left(H_{\mathrm{n}}, \mathrm{mg} / \mathrm{m}^{2}\right)$ was calculated by Eq. (3):

$H_{\mathrm{n}}=C_{\mathrm{n}} \times B_{\mathrm{n}}$

where $C_{\mathrm{n}}(\mathrm{mg} / \mathrm{kg})$ is the heavy metal concentrations of compartment, and $B_{\mathrm{n}}\left(\mathrm{kg} / \mathrm{m}^{2}\right)$ is the biomass of compartment.

\section{Statistical analyses}

Statistical analyses were performed using SPSS 16.0 and Origin 7.5 for Windows. The paired Student's $t$ test was used to evaluate the significant differences in heavy metal concentrations between roots and leaves, roots and stems, and stems and leaves for plant. Significant differences in heavy metal concentrations in leaves, stems, roots, and litters of $S$. salsa in different marshes were determined by one-way analysis of variance [ANOVA followed by Tukey's honest significant difference (HSD) test]. Before performing ANOVA, data were checked for their normality and homogeneity of variance, and where necessary, data were log-transformed. 


\section{Results}

Variations of heavy metals in plants and sediments

\section{Heavy metals in plants}

Temporal variations of heavy metal concentrations (Cr, Ni, $\mathrm{Cu}$, and $\mathrm{Pb}$ ) in $\mathrm{S}$. salsa of MM and LM were observed during the growing season (Figs. 2, 3, 4, and 5), and the values were generally in the order of $\mathrm{Cu}>\mathrm{Cr}>\mathrm{Pb}>\mathrm{Ni}$. Heavy metal concentrations in S. salsa at MM and LM were lower in the vigorous growth period, while those in late growth period were relatively higher. The maximums of $\mathrm{Cr}, \mathrm{Ni}$, and $\mathrm{Pb}$ concentrations in $S$. salsa of MM were observed on September 20, while those in S. salsa of LM occurred on September 20, August 31, and August 31, respectively. Differently, both the maximums of $\mathrm{Cu}$ concentrations in S. salsa of MM and LM occurred on October 19. Significant differences between roots and stems [ for $\mathrm{Ni}(p=0.029)$ and $\mathrm{Cu}$ $(p=0.000)]$, or roots and leaves [for $\mathrm{Cr}(p=0.038)$ ] were observed in $S$. salsa of MM, while those between roots and leaves $(p=0.011)$, or stems and leaves $(p=0.005)$ for $\mathrm{Pb}$ occurred in S. salsa of LM. Only Ni concentrations in stems $(p=0.046)$ and litters $(p=0.026)$ of $S$. salsa between MM and LM showed significant difference.

\section{Heavy metals in sediments}

Dissimilar temporal variations of heavy metal concentrations were observed in MM and LM topsoil (Fig. 6). Generally, the variations of $\mathrm{Cr}, \mathrm{Cu}$, and $\mathrm{Pb}$ concentrations in $\mathrm{MM}$ and $\mathrm{LM}$ were opposite before July 12 and were consistent until November 15, while those of Ni concentrations were opposite over all sampling periods. The maximums of $\mathrm{Cr}, \mathrm{Ni}, \mathrm{Cu}$, and $\mathrm{Pb}$ concentrations in MM were observed on August 9, while those of $\mathrm{Cr}$ and $\mathrm{Ni}$ concentrations and $\mathrm{Cu}$ and $\mathrm{Pb}$ concentrations in LM occurred on May 31 and August 9, respectively. Heavy metal concentrations in MM and LM were generally in the order of $\mathrm{Cr}>\mathrm{Ni}>\mathrm{Cu}>\mathrm{Pb}$, and only $\mathrm{Pb}$ concentrations showed a significant difference between them $(p<0.05)$. Except for $\mathrm{Ni}$ in $\mathrm{MM}$, most values were lower than the threshold of class I $(\mathrm{Cr} \leq 90 \mathrm{mg} / \mathrm{kg}, \mathrm{Cu} \leq 35 \mathrm{mg} / \mathrm{kg}, \mathrm{Zn}$ $\leq 100 \mathrm{mg} / \mathrm{kg}, \mathrm{Ni} \leq 40 \mathrm{mg} / \mathrm{kg}$ ) recommended by the Environmental Quality Standard for Soils of China (EQSS).

Transfers and allocations of heavy metals in plants

\section{Transfers of heavy metals in plants}

Temporal variations of heavy metal transportation were observed in S. salsa of MM and LM (Table 2). For Cr, the $\mathrm{R} / \mathrm{S}, \mathrm{R} / \mathrm{L}$, and $\mathrm{S} / \mathrm{L}$ ratios ranged from 0.51 to 4.53 , 1.13 to 8.88 , and 0.37 to 8.05 in $\mathrm{MM}$, while those in
LM ranged from 0.03 to $1.93,0.33$ to 3.01 , and 0.49 to 2.95. The $\mathrm{R} / \mathrm{S}, \mathrm{R} / \mathrm{L}$, and $\mathrm{S} / \mathrm{L}$ ratios for $\mathrm{Ni}, \mathrm{Cu}$, and $\mathrm{Pb}$ in $\mathrm{MM}$ ranged from 1.00 to $2.88,1.06$ to 1.27 , and 0.61 to $1.86(\mathrm{R} / \mathrm{S}) ; 0.90$ to $3.57,0.67$ to 1.60 , and 0.36 to $7.74(\mathrm{R} / \mathrm{L})$; and 0.32 to $1.97,0.56$ to 1.38 , and 0.19 to $1.55(\mathrm{~S} / \mathrm{L})$, while in $\mathrm{LM}$, the ranges were $0.30-2.42$, $0.87-2.14$, and $0.17-2.15(\mathrm{R} / \mathrm{S}) ; 0.15-2.44,0.73-3.11$, and $0.06-1.30(\mathrm{R} / \mathrm{L})$; and $0.46-1.76,0.66-1.48$, and $0.3-1.52(\mathrm{~S} / \mathrm{L})$, respectively. The $\mathrm{R} / \mathrm{L}$ and $\mathrm{R} / \mathrm{S}$ ratios for $\mathrm{Cr}$ and $\mathrm{Ni}$ in $\mathrm{MM}$ were mostly greater than 1 , while those in LM were mostly less than 1, indicating that, in $\mathrm{MM}$, the mobility of $\mathrm{Cr}$ and $\mathrm{Ni}$ from roots to aboveground parts was very low. During the growing season, the $\mathrm{R} / \mathrm{L}$ and $\mathrm{R} / \mathrm{S}$ ratios for $\mathrm{Cu}$ in $\mathrm{MM}$ and $\mathrm{LM}$ mostly approximated 1 , while those for $\mathrm{Pb}$ were mostly less than 1 .

\section{Allocations of heavy metals in plants}

Stocks of $\mathrm{Cr}, \mathrm{Ni}, \mathrm{Cu}$, and $\mathrm{Pb}$ in $\mathrm{MM}$ fell in the order of $\mathrm{Cu}>\mathrm{Cr}>\mathrm{Pb}>\mathrm{Ni}$ in $\mathrm{MM}$, while those in LM were in the order of $\mathrm{Cu}>\mathrm{Pb}>\mathrm{Cr}>\mathrm{Ni}$ (Fig. 7). The $\mathrm{Cr}, \mathrm{Ni}, \mathrm{Cu}$, and $\mathrm{Pb}$ stocks in $\mathrm{S}$. salsa of MM were $0.146-1.437,0.086$ $0.495,0.995-2.074$, and $0.158-0.998 \mathrm{mg} / \mathrm{m}^{2}$, while those in LM were $0.434-1.774,0.166-0.704,0.774-$ 2.260 , and $0.119-1.136 \mathrm{mg} / \mathrm{m}^{2}$, respectively. Temporal variations of $\mathrm{Cr}, \mathrm{Ni}, \mathrm{Cu}$, and $\mathrm{Pb}$ allocations in different parts of $S$. salsa were observed (Table 3). At the initial stage, the root was the main stock and the allocations of $\mathrm{Cr}$ and $\mathrm{Ni}$ ranged from 26.84 to $46.61 \%$ and 26.55 to $42.75 \%$ (in MM) and 18.14 to $54.05 \%$ and 17.69 to $37.52 \%$ (in LM), respectively. While at the final stage, litter was the main stock and the allocations of $\mathrm{Cr}$ and $\mathrm{Ni}$ reached $31.25-51.31 \%$ and $28.49-42.58 \%$ (in MM) and $36.73-48.60 \%$ and $41.70-57.87 \%$ (in LM), respectively. For $\mathrm{Cu}$ and $\mathrm{Pb}$, litter was the main stock during the growing season and the allocations ranged from 23.47 to $31.45 \%$ and 29.55 to $66.79 \%$ (in MM) and 22.59 to $31.87 \%$ and 33.30 to $60.64 \%$ (in LM).

\section{Bioaccumulation of heavy metals in plants}

Temporal dynamics of [AF] of heavy metals occurred in different parts of the plant (Fig. 8). The $[\mathrm{AF}]_{\text {plant }}$ of $\mathrm{Cr}, \mathrm{Ni}, \mathrm{Cu}$, and $\mathrm{Pb}$ in $\mathrm{LM}$, especially $[\mathrm{AF}]_{\text {root }}$ and $[\mathrm{AF}]_{\text {stem }}$ of $\mathrm{Cr}$ and $[\mathrm{AF}]_{\text {litter }}$ of $\mathrm{Ni}$, was generally higher than that in MM. Both $[\mathrm{AF}]_{\text {root }}$ and $[\mathrm{AF}]_{\text {stem }}$ in $\mathrm{MM}$ and $\mathrm{LM}$ were in the order of $\mathrm{Cu}>\mathrm{Pb}>\mathrm{Cr}>\mathrm{Ni}$, while both $[\mathrm{AF}]_{\text {leaf }}$ and $[\mathrm{AF}]_{\text {litter }}$ fell in the order of $\mathrm{Pb}>\mathrm{Cu}>\mathrm{Cr}>\mathrm{Ni}$. Except for $[\mathrm{AF}]_{\text {litter }}$ of $\mathrm{Pb}$ in $\mathrm{LM}$, the $[\mathrm{AF}]_{\text {plant }}$ of different heavy metals was less than 1 , implying that the accumulations of heavy metals in S. salsa were very low. 
Fig. 2 Cr concentrations in roots, stems, leaves, and litters of Suaeda salsa in middle marsh $(M M)$ and low marsh $(L M)$. Error bars indicate standard error of the means

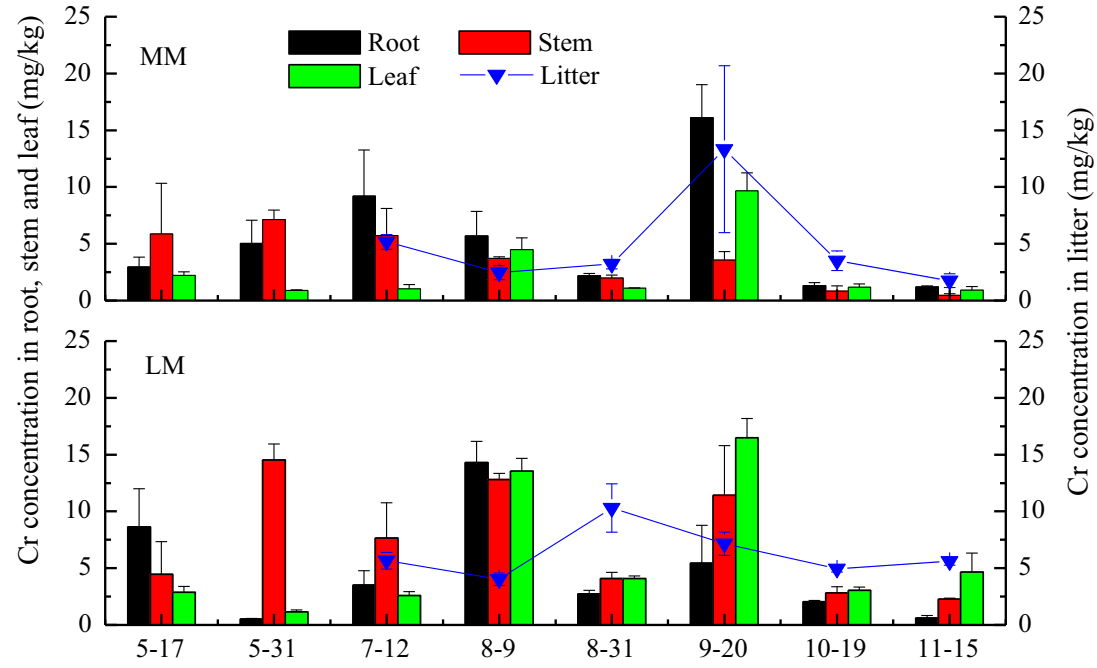

\section{Discussion}

Variations of heavy metals in plants and sediments

This study showed that both heavy metal concentrations and stocks in S. salsa at MM and LM presented temporal fluctuations, and similar results were drawn by previous studies (Duman et al. 2007; Ramirez et al. 2001). The temporal variations of heavy metals in plants were generally dependent on metabolic factor ("dilution effect" during growth), biological characteristics, and environmental factors (such as levels of metals in sediment and interactions between metals and other elements). The influence of the "dilution effect" during plant growth has been recognized as a major reason in explaining the temporal fluctuations of elements (Sun and Liu 2007). This paper indicated that $\mathrm{Cr}, \mathrm{Ni}, \mathrm{Cu}$, and $\mathrm{Pb}$ concentrations and stocks in plants were generally lower at the initial growth stage, which was referred to as slower uptake than growth rather than back transport or loss of the element. At the late growth stage, variations in plant biomass were normally less pronounced and differences in metal uptake or translocation, availability, or surface contamination might contribute more to the observed concentration changes. Differences in biological characteristics of $S$. salsa at MM and LM influenced the temporal variations of heavy metal concentrations in plants. As mentioned previously, S. salsa grown in LM was frequently affected by tide and ocean current, and under salt stress and seawater flooding conditions, their heights were much shorter than those in MM. During the growing season, the leaves and stems of $S$. salsa in LM were red-violet due to the accumulation of betacyanin. The betacyanins were probably involved in the regulation of the level of reactive oxygen species (ROS) in $S$. salsa (Wang et al. 2006), which might greatly influence the variations of heavy metals in different parts. Other studies also found that the degree of leaf carnification (Liu et al. 2006), leaf pigment
Fig. 3 Ni concentrations in roots, stems, leaves, and litters of Suaeda salsa in middle marsh $(M M)$ and low marsh $(L M)$. Error bars indicate standard error of the means

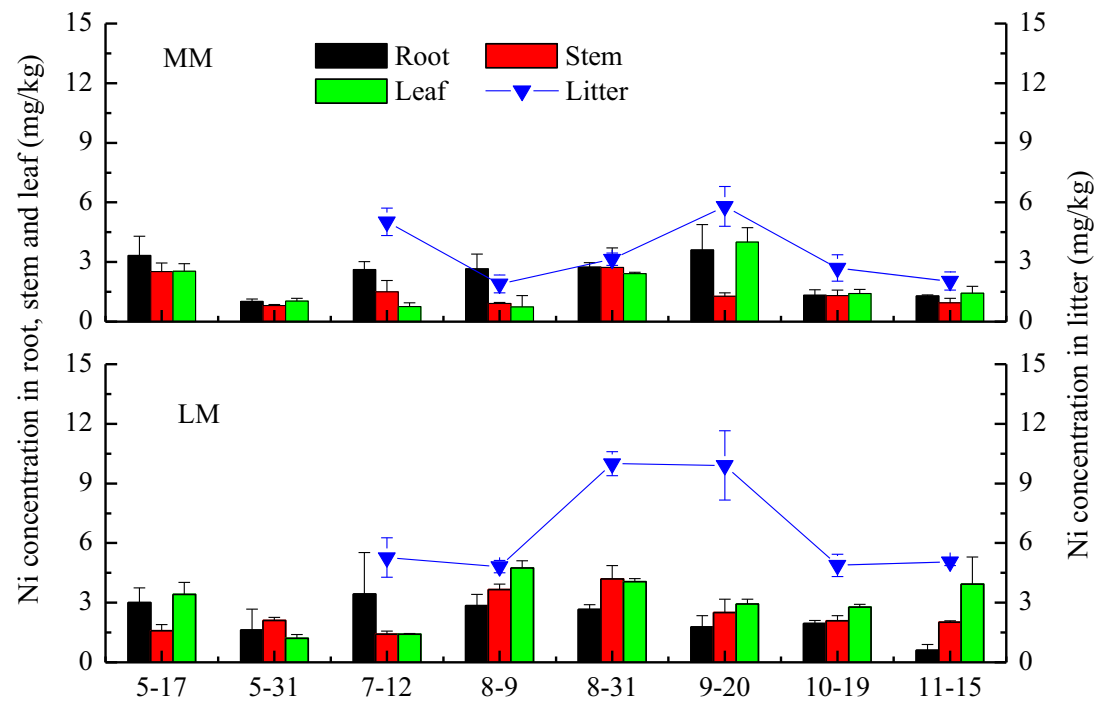


Fig. $4 \mathrm{Cu}$ concentrations in roots, stems, leaves, and litters of Suaeda salsa in middle marsh $(M M)$ and low marsh $(L M)$. Error bars indicate standard error of the means

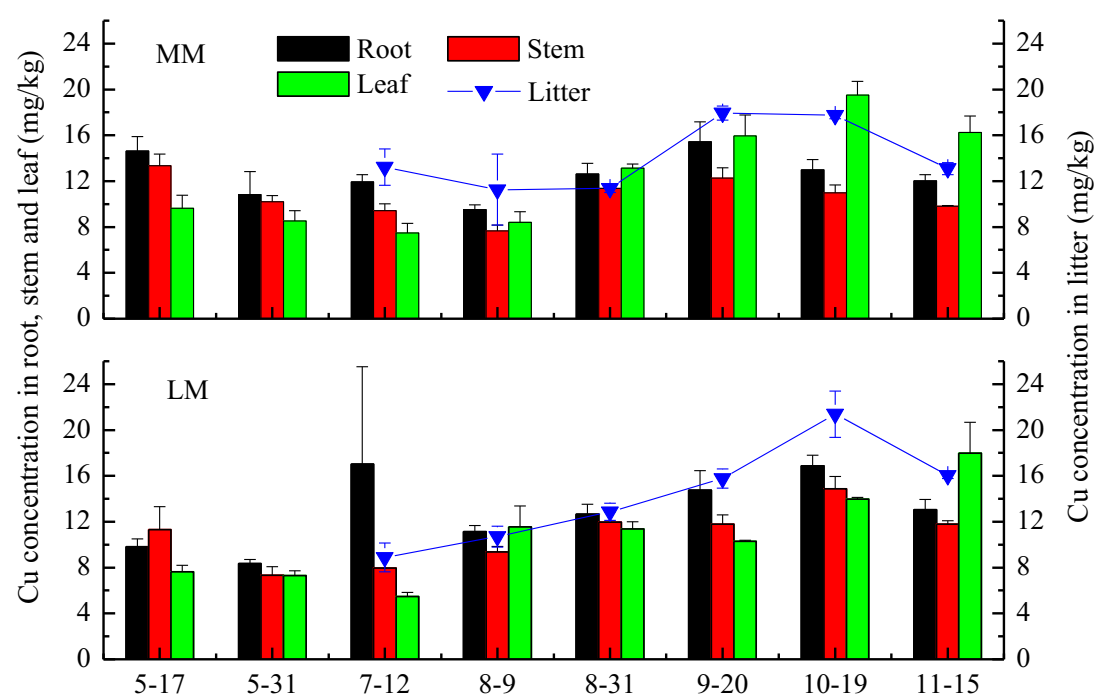

especially from June to July due to channel scouring in the lower reaches (Bai et al. 2012). The variations of water discharge and sediment loads could greatly affect the concentration of heavy metals. Bai et al. (2012) implied that the flow-sediment regulation potentially influenced the accumulation of heavy metals in the Yellow River. In this study, the maximums of heavy metal concentration in sediments (especially in MM) were observed in August 9 (Fig. 6), which was matched with the end time of the flow-sediment regulation scheme.

Environmental factors also played a significant role in sediment concentration and the accumulation of heavy metals in $S$. salsa of different marshes. In this study, heavy metal concentrations of $S$. salsa in MM and LM were different and significant differences occurred in stems $(F=4.797, p=0.046)$ and litters $(F=6.799, p=0.026)$ for Ni. As shown in Table 1, some environmental parameters in MM and LM, such as grain
Fig. $5 \mathrm{~Pb}$ concentrations in roots, stems, leaves, and litters of Suaeda salsa in middle marsh $(M M)$ and low marsh $(L M)$. Error bars indicate standard error of the means

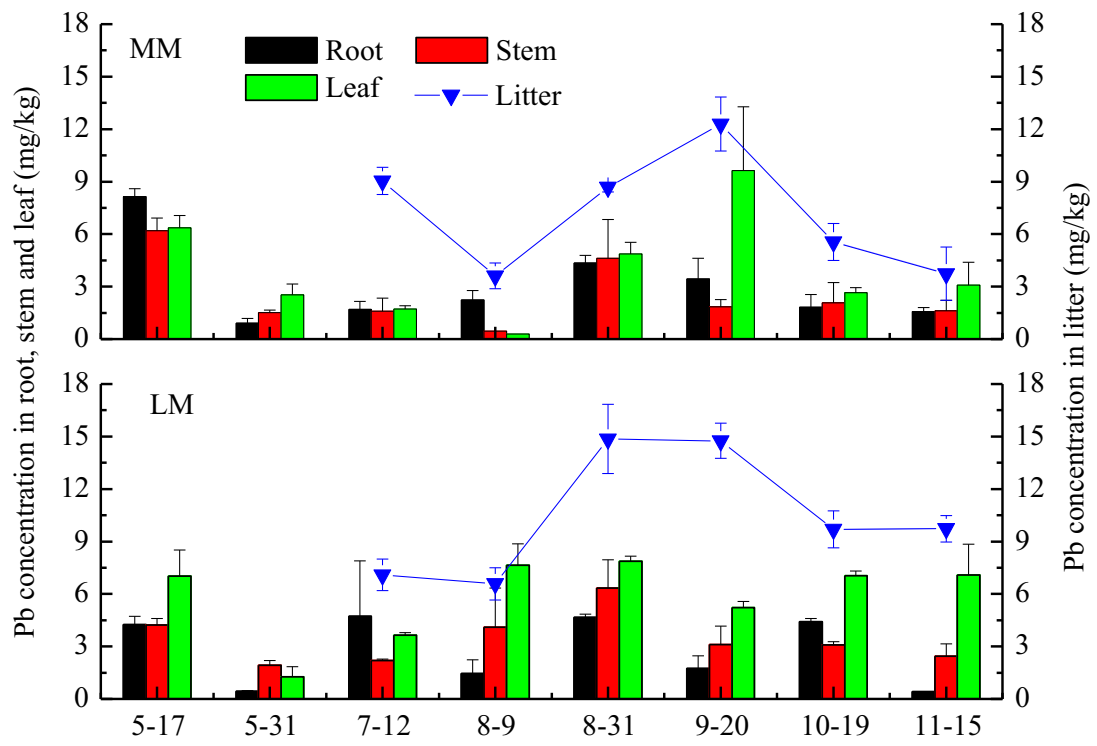


Fig. $6 \mathrm{Cr}, \mathrm{Ni}, \mathrm{Cu}$, and $\mathrm{Pb}$ concentrations in sediment. The threshold of class I $(\mathrm{Cr}$ $\leqq 90 \mathrm{mg} / \mathrm{kg} ; \mathrm{Ni} \leqq 40 \mathrm{mg} / \mathrm{kg} ; \mathrm{Cu}$ $\leqq 35 \mathrm{mg} / \mathrm{kg} ; \mathrm{Pb} \leqq 35 \mathrm{mg} / \mathrm{kg}$ ) regulated in the Environmental Quality Standard for Soil in China (EQSS) was set to represent the natural background levels of soils. $M M$ middle marsh, $L M$ low marsh
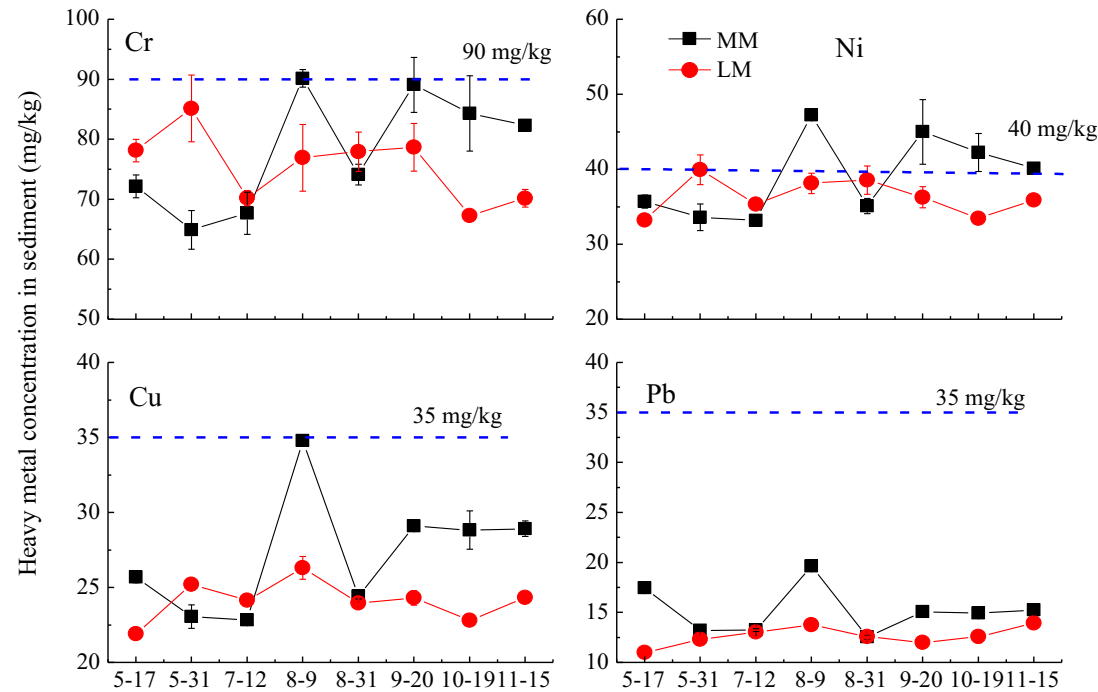

composition, soil organic matter (SOM), sediment salinity, $\mathrm{pH}$, sediment moisture content, and nutrients were greatly different. Higher levels of heavy metals occur in relatively fine-grained sediments since a fine-grained fraction of sediments is associated with metal-rich aluminosilicate. In general, metal contents decreased accordingly with increasing grain size in sediment (Lin et al. 2002). In this study, the percentages of clay and sand in MM (at 10-20 cm) were 12.17 and $23.15 \%$, while those in LM were 9.77 and $24.24 \%$, respectively. Thus, the difference of grain size in

Table 2 Roots/stems (R/S), roots/leaves (R/L), and stems/leaves $(\mathrm{S} / \mathrm{L})$ ratios in Suaeda salsa

\begin{tabular}{|c|c|c|c|c|c|c|c|c|c|c|}
\hline & Item & Ratio & 5-17 & $5-31$ & $7-12$ & $8-9$ & $8-31$ & 9-20 & $10-19$ & $11-15$ \\
\hline \multirow[t]{6}{*}{$\mathrm{Cr}$} & \multirow[t]{3}{*}{$\mathrm{MM}$} & $\mathrm{R} / \mathrm{S}$ & 0.51 & 0.71 & 1.60 & 1.53 & 1.10 & 4.53 & 1.63 & 2.67 \\
\hline & & $\mathrm{R} / \mathrm{L}$ & 1.33 & 5.69 & 8.88 & 1.27 & 2.01 & 1.67 & 1.13 & 1.31 \\
\hline & & $\mathrm{S} / \mathrm{L}$ & 2.64 & 8.05 & 5.53 & 0.83 & 1.83 & 0.37 & 0.69 & 0.49 \\
\hline & \multirow[t]{3}{*}{$\mathrm{LM}$} & $\mathrm{R} / \mathrm{S}$ & 1.93 & 0.03 & 0.46 & 1.12 & 0.67 & 0.48 & 0.72 & 0.27 \\
\hline & & $\mathrm{R} / \mathrm{L}$ & 3.01 & 0.43 & 1.36 & 1.06 & 0.67 & 0.33 & 0.67 & 0.13 \\
\hline & & $\mathrm{S} / \mathrm{L}$ & 1.56 & 12.49 & 2.95 & 0.95 & 1.00 & 0.69 & 0.92 & 0.49 \\
\hline \multirow[t]{6}{*}{$\mathrm{Ni}$} & \multirow[t]{3}{*}{ MM } & $\mathrm{R} / \mathrm{S}$ & 1.32 & 1.27 & 1.75 & 2.88 & 1.00 & 2.83 & 1.02 & 1.36 \\
\hline & & $\mathrm{R} / \mathrm{L}$ & 1.31 & 1.00 & 3.46 & 3.57 & 1.14 & 0.90 & 0.94 & 0.90 \\
\hline & & $\mathrm{S} / \mathrm{L}$ & 0.99 & 0.78 & 1.97 & 1.24 & 1.13 & 0.32 & 0.92 & 0.66 \\
\hline & \multirow[t]{3}{*}{ LM } & $\mathrm{R} / \mathrm{S}$ & 1.89 & 0.77 & 2.42 & 0.78 & 0.64 & 0.71 & 0.93 & 0.30 \\
\hline & & $\mathrm{R} / \mathrm{L}$ & 0.88 & 1.36 & 2.44 & 0.60 & 0.66 & 0.60 & 0.70 & 0.15 \\
\hline & & $\mathrm{S} / \mathrm{L}$ & 0.46 & 1.76 & 1.01 & 0.77 & 1.03 & 0.85 & 0.75 & 0.51 \\
\hline \multirow[t]{6}{*}{$\mathrm{Cu}$} & \multirow[t]{3}{*}{$\mathrm{MM}$} & $\mathrm{R} / \mathrm{S}$ & 1.10 & 1.06 & 1.27 & 1.24 & 1.11 & 1.26 & 1.18 & 1.23 \\
\hline & & $\mathrm{R} / \mathrm{L}$ & 1.52 & 1.27 & 1.60 & 1.13 & 0.96 & 0.97 & 0.67 & 0.74 \\
\hline & & $\mathrm{S} / \mathrm{L}$ & 1.38 & 1.19 & 1.26 & 0.91 & 0.87 & 0.77 & 0.56 & 0.60 \\
\hline & \multirow[t]{3}{*}{ LM } & $\mathrm{R} / \mathrm{S}$ & 0.87 & 1.14 & 2.14 & 1.19 & 1.06 & 1.25 & 1.13 & 1.11 \\
\hline & & $\mathrm{R} / \mathrm{L}$ & 1.28 & 1.14 & 3.11 & 0.96 & 1.12 & 1.43 & 1.21 & 0.73 \\
\hline & & $\mathrm{S} / \mathrm{L}$ & 1.48 & 1.00 & 1.45 & 0.81 & 1.05 & 1.15 & 1.06 & 0.66 \\
\hline \multirow[t]{6}{*}{$\mathrm{Pb}$} & \multirow[t]{3}{*}{ MM } & $\mathrm{R} / \mathrm{S}$ & 1.32 & 0.61 & 1.07 & 4.99 & 0.94 & 1.86 & 0.88 & 0.98 \\
\hline & & $\mathrm{R} / \mathrm{L}$ & 1.28 & 0.36 & 0.99 & 7.74 & 0.90 & 0.36 & 0.69 & 0.51 \\
\hline & & $\mathrm{S} / \mathrm{L}$ & 0.97 & 0.60 & 0.93 & 1.55 & 0.95 & 0.19 & 0.79 & 0.52 \\
\hline & \multirow[t]{3}{*}{ LM } & $\mathrm{R} / \mathrm{S}$ & 1.01 & 0.23 & 2.15 & 0.36 & 0.74 & 0.56 & 1.43 & 0.17 \\
\hline & & $\mathrm{R} / \mathrm{L}$ & 0.60 & 0.35 & 1.30 & 0.19 & 0.59 & 0.33 & 0.63 & 0.06 \\
\hline & & $\mathrm{S} / \mathrm{L}$ & 0.60 & 1.52 & 0.61 & 0.54 & 0.80 & 0.60 & 0.44 & 0.35 \\
\hline
\end{tabular}

MM, Suaeda salsa in middle marsh; LM, S. salsa in low marsh 
Fig. 7 Standing stocks of $\mathrm{Cr}$, Ni, $\mathrm{Cu}$, and $\mathrm{Pb}$ in Suaeda salsa of middle marsh $(M M)$ and low marsh $(L M)$
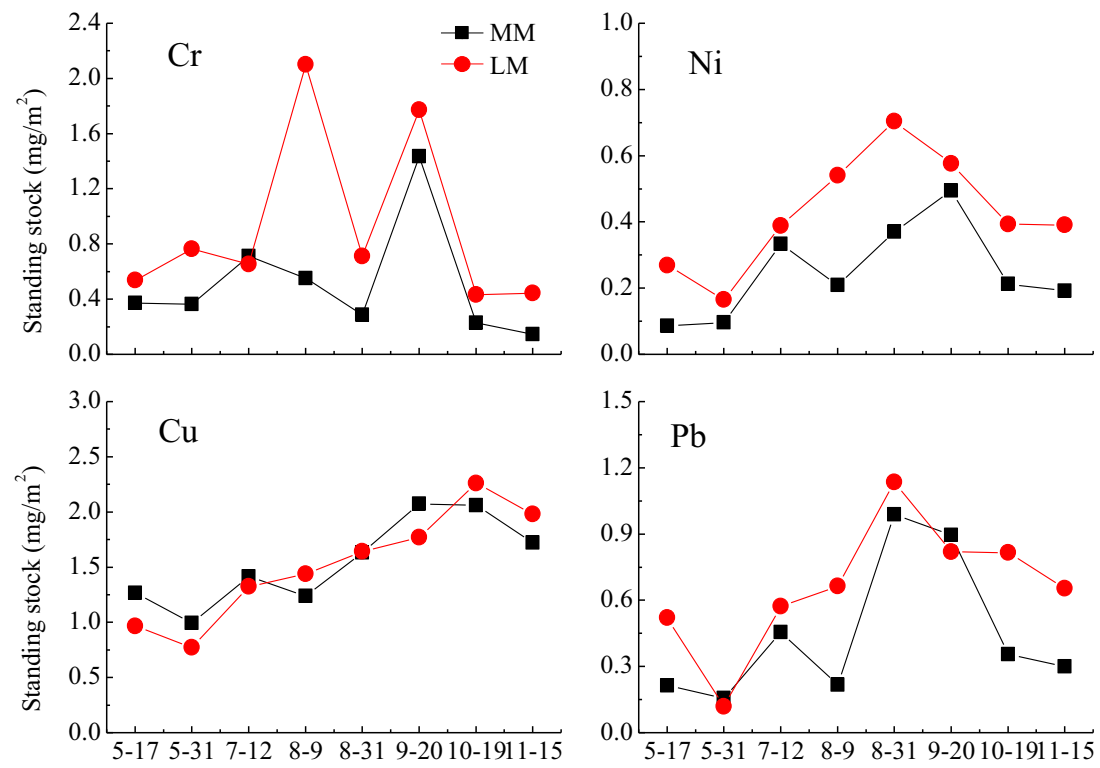

MM and LM sediments might have a great influence on the concentrations of heavy metals. SOM generally acts as a major sink for metals due to its strong complexing capacity (Du Laing et al. 2009), and this was tested in this study. The higher concentrations of heavy metals in surface sediment of MM corresponded well to its higher SOM content (Table 1, Fig. 6). Current studies have indicated that salinity could affect the mobility and availability of trace metals (Du Laing et al. 2008, 2009). Since chlorocomplexation decreases the activity of free ion in the sediment solution and increases desorption, trace metal (especially $\mathrm{Cd}$ ) can be mobilized as soluble chloride complexes (Hahne and Kroontje 1973). Besides the effect of complexation, an increase of the salinity is associated with an increase in the concentrations of major cations ( $\mathrm{Na}, \mathrm{K}, \mathrm{Ca}$, and $\mathrm{Mg}$ ) that compare with heavy metals for the sorption sites (Tam and Wong 1999). Gambrell et al. (1991) studied the salinity effects during the oxidation of reduced metal-polluted brackish marsh sediments and observed that soluble $\mathrm{Cr}$ and $\mathrm{Cu}$ were enhanced with increasing salinity, whereas salinity did not significantly affect the mobility of $\mathrm{Ni}$ and $\mathrm{Pb}$. In this paper, $\mathrm{Cr}$ concentrations in $\mathrm{S}$. salsa at LM were higher than those at MM (Fig. 2), which might be correlated with the higher salinity in LM (Table 1). However, $\mathrm{Cu}$ concentration did not increase with increasing salinity, which was probably due to the complex interactions of salinity and other environmental factors (such as sediment moisture and $\mathrm{pH}$ ). A drop in $\mathrm{pH}$ prevents the transfer of most trace metals from the water phase to the sediment and/or causes desorption from the sediments (Calmano et al. 1993). Samecka-Cymerman and Kenpers (2001) also found that the concentrations of heavy metals in water and soil were usually negatively correlated with $\mathrm{pH}$. The influence of $\mathrm{pH}$ on the mobilization of heavy metal might be due to hydroxyl. Hahne and Kroontje (1973) indicated that both the hydroxy contributed to the mobilization of heavy metal ions and hydrolysis of heavy metal ions were important factors affecting the solubility of the sparingly soluble salts of metal ions. As shown in Table 1, the sediment moisture was higher in LM compared to MM. Higher moisture usually resulted in variations of chemical properties in sediment and underwent a series of sequential redox reactions. Metals respond in different ways to changes in oxidation-reduction potential. For example, reduction of the very toxic $\mathrm{Cr}$ (VI) to less toxic trivalent $\mathrm{Cr}$ in marsh sediment (Pardue and Patrick 1995), $\mathrm{Cu}$ (II) to $\mathrm{Cu}$ (I) under slightly alkaline conditions (Simpson et al. 2000) and subsequently leading to $\mathrm{Cu}_{2} \mathrm{~S}$ precipitation due to the effects of numerous electron donors (e.g., Fe (II), sulfur compounds) and bacteria acting as catalysts (Du Laing et al. 2009). Previous studies have shown that the Fe and $\mathrm{S}$ contents in sediment of the Yellow River estuary were very high, and the values were $16.49 \sim 33.11 \mathrm{~g} / \mathrm{kg}$ for Fe (Sun et al. 2013c), 300 620 mg/kg for TS (Sun et al. 2009), and 62 $150 \mathrm{mg} / \mathrm{kg}$ for sulfate (Fan et al. 2010). This indicated that numerous $\mathrm{Cu}_{2} \mathrm{~S}$ precipitation would occur across the intertidal sediment due to the supply of enough electron donors, which might cause the standing stocks of $\mathrm{Cu}$ in $\mathrm{MM}$ to be closed with those in MM. Differently, standing stocks of $\mathrm{Cr}$, $\mathrm{Ni}$, and $\mathrm{Pb}$ in $\mathrm{LM}$ were higher than those in MM, which was dependent on the different oxidation-reduction conditions in sediments of $\mathrm{MM}$ and LM. As mentioned previously, LM is more frequently affected by tide fluctuation compared to MM, which caused the oxidationreduction conditions in LM sediments to vary greatly. Salomons et al. (1987) also found that variations from an anoxic to oxic environment might cause a remobilization of some trace metals.

Heavy metal concentrations in sediment also affected their variations in plants by influencing the absorption for effective heavy metals ions. Expect for $\mathrm{Ni}$ in $\mathrm{MM}$, heavy metals in marsh sediment were lower than the threshold of class I $(\mathrm{Cr}$ $\leq 90 \mathrm{mg} / \mathrm{kg}, \mathrm{Cu} \leq 35 \mathrm{mg} / \mathrm{kg}, \mathrm{Zn} \leq 100 \mathrm{mg} / \mathrm{kg}, \mathrm{Ni} \leq 40 \mathrm{mg} / \mathrm{kg}$ ) 
Table 3 Allocations of $\mathrm{Cr}, \mathrm{Ni}, \mathrm{Cu}$, and $\mathrm{Pb}$ in Suaeda salsa of different marshes (\%)

\begin{tabular}{|c|c|c|c|c|c|c|c|c|c|c|}
\hline Items & & & $5-17$ & $5-31$ & $7-12$ & $8-9$ & $8-31$ & 9-20 & $10-19$ & $11-15$ \\
\hline \multirow[t]{8}{*}{$\mathrm{Cr}$} & \multirow[t]{4}{*}{ MM } & Root & 26.84 & 46.61 & 43.54 & 34.83 & 25.82 & 37.76 & 19.47 & 27.86 \\
\hline & & Stem & 53.04 & 45.19 & 27.13 & 22.72 & 23.51 & 8.34 & 11.98 & 10.44 \\
\hline & & Leaf & 20.12 & 8.19 & 4.90 & 27.42 & 12.87 & 22.65 & 17.23 & 21.26 \\
\hline & & Litter & - & - & 24.43 & 15.02 & 37.79 & 31.25 & 51.31 & 40.45 \\
\hline & \multirow[t]{4}{*}{ LM } & Root & 54.05 & 49.14 & 18.14 & 51.35 & 12.83 & 10.32 & 15.84 & 4.61 \\
\hline & & Stem & 28.00 & 45.75 & 39.35 & 20.51 & 19.29 & 21.66 & 21.93 & 17.31 \\
\hline & & Leaf & 17.95 & 5.11 & 13.35 & 21.69 & 19.28 & 31.29 & 23.76 & 35.45 \\
\hline & & Litter & - & - & 29.16 & 6.44 & 48.60 & 36.73 & 38.47 & 42.64 \\
\hline \multirow[t]{8}{*}{$\mathrm{Ni}$} & \multirow[t]{4}{*}{$\mathrm{MM}$} & Root & 39.71 & 35.86 & 26.55 & 42.75 & 24.86 & 24.56 & 21.11 & 22.57 \\
\hline & & Stem & 29.98 & 28.17 & 15.14 & 14.82 & 24.74 & 8.69 & 13.84 & 16.62 \\
\hline & & Leaf & 30.30 & 35.97 & 7.67 & 11.99 & 21.90 & 27.26 & 22.47 & 25.07 \\
\hline & & Litter & - & - & 50.64 & 30.44 & 28.49 & 39.49 & 42.58 & 35.74 \\
\hline & \multirow[t]{4}{*}{ LM } & Root & 37.52 & 32.97 & 29.84 & 17.69 & 12.75 & 10.36 & 16.60 & 5.17 \\
\hline & & Stem & 19.80 & 42.70 & 12.31 & 22.78 & 20.06 & 14.62 & 17.89 & 17.42 \\
\hline & & Leaf & 42.68 & 24.32 & 12.22 & 29.56 & 19.43 & 17.15 & 23.81 & 33.90 \\
\hline & & Litter & - & - & 45.64 & 29.97 & 47.76 & 57.87 & 41.70 & 43.51 \\
\hline \multirow[t]{8}{*}{$\mathrm{Cu}$} & \multirow[t]{4}{*}{ MM } & Root & 38.92 & 36.64 & 28.39 & 25.82 & 26.05 & 25.04 & 21.23 & 23.51 \\
\hline & & Stem & 35.44 & 34.49 & 22.37 & 20.82 & 23.42 & 19.93 & 17.95 & 19.17 \\
\hline & & Leaf & 25.64 & 28.86 & 17.78 & 22.79 & 27.06 & 25.90 & 31.86 & 31.73 \\
\hline & & Litter & - & - & 31.45 & 30.58 & 23.47 & 29.13 & 28.97 & 25.59 \\
\hline & \multirow[t]{4}{*}{ LM } & Root & 34.09 & 36.35 & 43.30 & 26.04 & 25.94 & 28.03 & 25.14 & 22.16 \\
\hline & & Stem & 39.39 & 31.85 & 20.21 & 21.89 & 24.49 & 22.43 & 22.16 & 20.04 \\
\hline & & Leaf & 26.53 & 31.80 & 13.91 & 27.03 & 23.25 & 19.56 & 20.83 & 30.56 \\
\hline & & Litter & - & - & 22.59 & 25.04 & 26.32 & 29.99 & 31.87 & 27.24 \\
\hline \multirow[t]{8}{*}{$\mathrm{Pb}$} & \multirow[t]{4}{*}{ MM } & Root & 39.39 & 13.51 & 12.56 & 34.71 & 14.86 & 12.90 & 17.21 & 11.78 \\
\hline & & Stem & 29.92 & 32.36 & 7.98 & 6.96 & 15.73 & 4.70 & 13.21 & 12.04 \\
\hline & & Leaf & 30.69 & 54.13 & 12.66 & 2.48 & 39.86 & 36.21 & 17.18 & 34.44 \\
\hline & & Litter & - & - & 66.79 & 55.85 & 29.55 & 46.19 & 52.41 & 41.74 \\
\hline & \multirow[t]{4}{*}{ LM } & Root & 27.43 & 8.99 & 27.82 & 7.36 & 13.82 & 5.11 & 18.22 & 0.76 \\
\hline & & Stem & 27.22 & 54.87 & 9.08 & 20.71 & 18.78 & 12.79 & 12.76 & 12.62 \\
\hline & & Leaf & 45.35 & 36.14 & 21.39 & 38.63 & 23.35 & 21.45 & 29.04 & 36.52 \\
\hline & & Litter & - & - & 41.72 & 33.30 & 44.06 & 60.64 & 39.98 & 50.10 \\
\hline
\end{tabular}

MM, Suaeda salsa in middle marsh; LM, S. salsa in low marsh

recommended by the Environmental Quality Standard for Soils of China (EQSS) (GB 15618-1995), which was correlated with the better conservation of the National Natural Reserve of the Yellow River Delta. This study also indicated that both heavy metals in sediments of MM and LM decreased in the order of $\mathrm{Cr}>\mathrm{Ni}>\mathrm{Cu}>\mathrm{Pb}$, but the values in $\mathrm{MM}$ were much higher (Fig. 6). Differently, the stocks of heavy metals in $S$. salsa of MM were lower compared to LM. There were two probable reasons. For one thing, as mentioned above, environmental factors affected the accumulation of heavy metals in S. salsa of MM and LM. Higher sediment salinity and moisture and other physicochemical properties might increase the mobility and absorption of heavy metals in S. salsa of LM. For another, the accumulation factor of heavy metals in marsh plants from sediment reflected the capability of the plants to accumulate heavy metals from the surrounding environment (Zhang et al. 2011). In this study, the $[\mathrm{AF}]_{\text {plant }}$ of $\mathrm{Cr}, \mathrm{Ni}, \mathrm{Cu}$, and $\mathrm{Pb}$ in $\mathrm{LM}$ was generally higher than that in $\mathrm{MM}$, which might be explained as the uptakes of $\mathrm{Cr}, \mathrm{Ni}, \mathrm{Cu}$, and $\mathrm{Pb}$ by bio-tissues were much higher in LM (KabataPendias and Pendias 2001; Yang et al. 2008).

Heavy metal accumulation in $S$. salsa and potential for phytoremediation

$\mathrm{Cr}$ is regarded toxic to plant with concentrations greater than $0.5 \mathrm{mg} / \mathrm{kg}$ (Bonanno and Lo Giudice 2010). In this study, both $\mathrm{Cr}$ concentrations in $S$. salsa at MM and LM exceeded the 

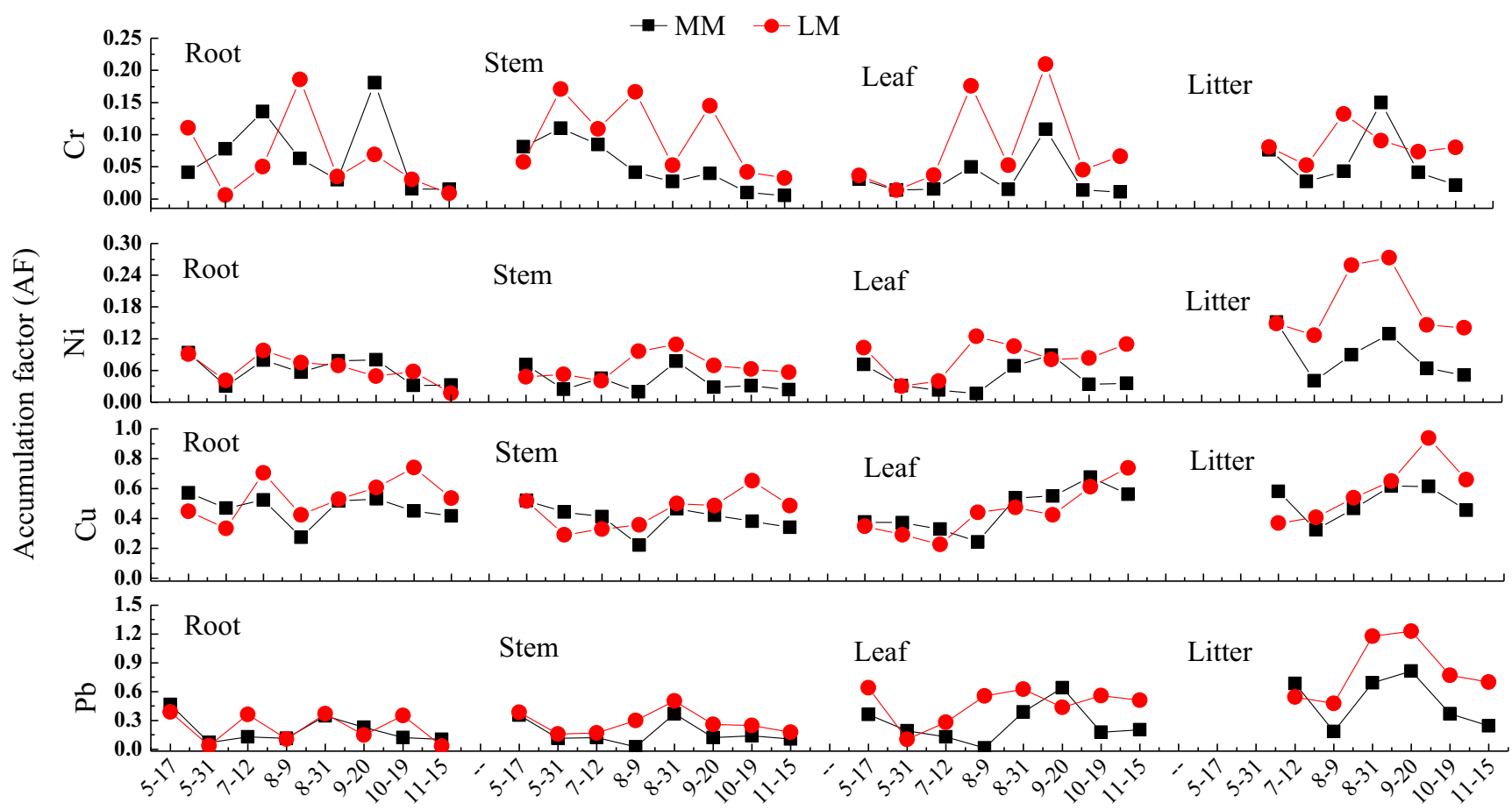

Fig. 8 Accumulation factor for roots, stems, leaves, and litters in Suaeda salsa of middle marsh (MM) and low marsh (LM)

phototoxic threshold (Fig. 2), indicating that intertidal plants showed serious $\mathrm{Cr}$ contamination. This study also indicated that the mobility of $\mathrm{Cr}$ differed among plants or tissues. It was found that the $\mathrm{R} / \mathrm{L}$ and $\mathrm{R} / \mathrm{S}$ ratios for $\mathrm{Cr}$ in $\mathrm{MM}$ were mostly greater than 1 , indicating that the mobility of $\mathrm{Cr}$ from the roots to shoots or leaves was very weak. Similar results were drawn by Baldantioni et al. (2004). The reason for the low mobility of $\mathrm{Cr}$ from roots to shoots might be due to the metabolism of the element (Shewry and Peterson 1974). By comparison, the $\mathrm{R} / \mathrm{L}$ and $\mathrm{R} / \mathrm{S}$ ratios for $\mathrm{Cr}$ in $\mathrm{LM}$ were mostly less than 1 , which was consistent with Kähkönen et al. (1997) who found that Elodea canadensis generally accumulated more $\mathrm{Cr}$ in the leaves than in the roots or shoots. $\mathrm{Ni}$ is thought to have toxic effects on plants. The mobility of $\mathrm{Ni}$ in plants varies between species, from mobile in some plants (Tiffin 1971; Thiesen and Blincoe 1988) to immobile in others (Sajwan et al. 1996). In this study, the R/L and R/S ratios for Ni in S. salsa at MM were mostly greater than 1 , while those at LM were less than 1, indicating that $\mathrm{Ni}$ was immobile in the former and mobile in the latter. According to Bonanno and Lo Giudice (2010), Ni concentrations in plants were poisonous over $5 \mathrm{mg} / \mathrm{kg}$. In this study, the majority of $\mathrm{Ni}$ concentrations in the shoots and roots were below $5 \mathrm{mg} / \mathrm{kg}$ except the values in the litters, indicating that Ni accumulated in $S$. salsa might not lead to toxic effect. $\mathrm{Cu}$ is a vital plant nutrition and needed for various enzymatic activities of oxidation-reduction (Fürtig et al. 1999) and will cause toxic effects as the concentrations in plants greater than $15 \sim 20 \mathrm{mg} / \mathrm{kg}$ (Kabata-Pendias and Pendias 2001). Borkert et al. (1998) also found that $\mathrm{Cu}$ appeared to be toxic to corn and rice at plant concentrations exceeding $20 \mathrm{mg} / \mathrm{kg}$. In this study, the Cu concentrations in S. salsa at MM and LM were below the phytotoxic threshold (Fig. 4), indicating that $\mathrm{Cu}$ contamination was not serious in plants. $\mathrm{Cu}$ is generally accumulated in the roots and seldom transported to aboveground parts (Baldantoni et al. 2009). However, we drew a different result. During the growing season, the $\mathrm{R} / \mathrm{L}$ and $\mathrm{R} / \mathrm{S}$ ratios for $\mathrm{Cu}$ in $S$. salsa at MM and LM were less than or approximated 1, indicating that a fraction of $\mathrm{Cu}$ in roots were transported to aboveground parts. The reason might be related to the low concentration of $\mathrm{Cu}$ in sediments of the Yellow River estuary (Fig. 6). Fürtig et al. (1999) indicated that, only under long-term exposure, high $\mathrm{Cu}$ concentrations might affect root energy metabolism, while in the low concentration, $\mathrm{Cu}$ would be transferred well to stems and leaves. $\mathrm{Pb}$ is not essential in plant organisms and can prove toxic. Wu et al. (2012) found that $\mathrm{Pb}$ could induce osmotic and oxidative stresses and disturbances in energy metabolism in $S$. salsa after exposure for 1 month. According to Ross (1994), $\mathrm{Pb}$ concentrations were considered to have toxic effect on plants as the values exceeded the phytotoxic range $(30 \sim 300 \mathrm{mg} / \mathrm{kg}) . \mathrm{Pb}$ concentrations found in all organs of $S$. salsa ranged from 0.29 to $14.8 \mathrm{mg} / \mathrm{kg}$, which were far lower than the phytotoxic range. Although $\mathrm{Pb}$ concentrations in stems and leaves were higher than those in roots $(\mathrm{R} / \mathrm{L}<1.0$, $\mathrm{R} / \mathrm{S}<1.0$ ), this could not verify that the $\mathrm{Pb}$ in $S$. salsa had strong mobility since previous studies have indicated that exhaust fumes were one of the important sources of $\mathrm{Pb}$ pollution and the aboveground organs of plant could directly accumulated $\mathrm{Pb}$ from surrounding environment (Ross 1994; Mohammed et al. 2011). 
Regarding translocation of metals to aboveground tissues, three strategies are known to be employed by plants (Baker 1981). With the exclusion strategy, shoot concentrations are kept low until a critical sediment concentration is reached, toxicity ensues, and unrestricted metal transport results. With the indicator strategy, uptake and transport to shoots are passively regulated so that tissue concentrations are proportional to environmental concentration. With the accumulator strategy, metals are actively concentrated in plant tissues, reflecting a highly specialized physiology (Windham et al. 2003). In this study, the allocation ratios of $\mathrm{Cr}, \mathrm{Ni}$, and $\mathrm{Pb}$ in roots and stems decreased during the growing season, while those in litters increased. Allocations of $\mathrm{Cr}, \mathrm{Ni}$, and $\mathrm{Pb}$ in $\mathrm{S}$. salsa litters reached 31.25-51.31, 28.4942.58, and 29.55-66.79 \% (in MM) and 36.73-48.60, 41.7057.87 , and $33.30-60.64 \%$ (in LM), respectively (Table 3), which indicated that the heavy metals (especially $\mathrm{Cr}, \mathrm{Ni}$, and $\mathrm{Pb}$ ) uptaken by $S$. salsa could be greatly excluded by litter fall. As mentioned above, although intertidal sediments of the Yellow River estuary were not contaminated by heavy metals, Ni had high eco-toxic risk of exposure due to its values exceeded the threshold of Class I ( $40 \mathrm{mg} / \mathrm{kg}$ ) occasionally. Because the loading of heavy metals in the Yellow River estuary is increasing (State Oceanic Administration of China 2013), intertidal sediments may be seriously contaminated if no effective measures are taken to control the import of pollutants in the future. Thus, the use of biomonitors living and growing in intertidal zone could yield valuable information not only on the presence of anthropogenic stressors but, more importantly, on the adverse influence the stressors are having on the environment (Ngayila et al. 2009; Chang et al. 2009). According to the different capacity for metal uptake, species able to accumulate relatively high metal concentrations in the aboveground tissues could be good candidates for phytoextraction (Deng et al. 2004). In the intertidal zone of the Yellow River estuary, $S$. salsa is the most prevalent halophytes and it has strong adaptations to environmental stresses (such as high salinity, flooding, and sediment burial) (Han et al. 2005). According to the present results, although heavy metal concentrations in sediment were higher in MM, their stocks in S. salsa were much lower compared to LM. Cr and Ni in S. salsa at LM also had greater mobility compared with those at MM. In addition, the $[\mathrm{AF}]_{\text {plant }}$ of $\mathrm{Cr}, \mathrm{Ni}, \mathrm{Cu}$, and $\mathrm{Pb}$ in $\mathrm{LM}$, especially $[\mathrm{AF}]_{\text {root }}$ and $[\mathrm{AF}]_{\text {stem }}$ of $\mathrm{Cr}$ and $[\mathrm{AF}]_{\mathrm{litter}}$ of $\mathrm{Ni}$, was much higher than that in MM. These indicated that the $S$. salsa at LM had many advantages which made it an appropriate test species for all four heavy metals.

\section{Conclusion}

Heavy metal concentrations of $S$. salsa in MM and LM were different and both had temporal variations over all sampling periods. The metal concentration quotient for roots/stems
$(\mathrm{R} / \mathrm{S})$, roots/leaves $(\mathrm{R} / \mathrm{L})$, stems/leaves $(\mathrm{S} / \mathrm{L})$, and accumulation factors $[\mathrm{AF}]$ indicated that $S$. salsa grown in LM was more suitable for potential biomonitor or phytoremediation of $\mathrm{Cr}, \mathrm{Ni}, \mathrm{Cu}$, and $\mathrm{Pb}$ if intertidal sediments were seriously contaminated with increasing of pollutants loading (especially heavy metals) in the Yellow River estuary. Thus, the role of $S$. salsa at LM should be seriously considered when planning activities of biomonitor or phytoremediation in intertidal zone of the Yellow River estuary in the future.

Acknowledgments The authors would like to acknowledge the financial support of the National Nature Science Foundation of China (No. 41371104, 41171424), the "1-3-5" Strategy Plan Program of the Yantai Institute of Coastal Zone Research of the Chinese Academy of Sciences (No. Y254021031), the Key Research Program of the Chinese Academy of Sciences (No. KZZD-EW-14), and the Talents Program of the Youth Innovation Promotion Association, Chinese Academy of Sciences (No. Y129091041).

\section{References}

Abrahim GMS, Parker RJ (2008) Assessment of heavy metal enrichment factors and the degree of contamination in marine sediments from Tamaki Estuary, Auckland, New Zealand. Environ Monit Assess 136(1-3):227-238

Bai JH, Xiao R, Cui BS, Zhang KJ, Wang Q, Liu X, Huang L (2011) Assessment of heavy metal pollution in wetland soils from the young and old reclaimed regions in the Pearl River Estuary, South China. Environ Pollut 159(3):817-824

Bai JH, Xiao R, Zhang KJ, Gao HF (2012) Arsenic and heavy metal pollution in wetland soils from tidal freshwater and salt marshes before and after the flow-sediment regulation regime in the Yellow River Delta, China. J Hydrol 450:244-253

Baker AJ (1981) Accumulation and excluders - strategies in the response of plants to heavy metals. J Plant Nutr 3:643-654

Baldantioni D, Alfani A, Di Tommasi P, Bartoli G, De Santo AV (2004) Assessment of macro and microelement accumulation capability of two aquatic plants. Environ Pollut 130:149-156

Baldantoni D, Ligrone R, Alfani A (2009) Macro- and trace-element concentrations on leaves and roots of Phragmites australis in a volcanic lake in Southern Italy. J Geochem Explor 101:66-174

Bonanno G, Lo Giudice R (2010) Heavy metal bioaccumulation by the organs of Phragmites australis (common reed) and their potential use as contamination indicators. Ecol Indic 10:639-645

Borkert CM, Cox FR, Tucker MR (1998) Zinc and copper toxicity in peanut, soybean, rice and corn in soil mixtures. Commun Soil Sci Plant Anal 29:2991-3005

Caeiro S, Costa MH, Ramos TB, Fernandes F, Silveira N, Coimbra A, Medeiros G, Painho M (2005) Assessing heavy metal contamination in Sado Estuary sediment: an index analysis approach. Ecol Indic 5(2):151-169

Calmano W, Hong J, Förstner U (1993) Binding and mobilization of heavy metals in contaminated sediments affected by $\mathrm{pH}$ and redox potential. Water Sci Technol 28:223-235

Chaney RL, Malik M, Li YM, Brown SL, Brewer EP, Angle JS, Barker AJ (1997) Phytoremediation of soil metals. Environ Biotechnol 8: 279-284

Chang JS, Yoon IH, Kim KW (2009) Heavy metal and arsenic accumulating fern species as potential ecological indicators in Ascontaminated abandoned mines. Ecol Indic 9:1275-1279 
Cui BS, Yang QC, Yang ZF, Zhang KJ (2009) Evaluating the ecological performance of wetland restoration in the Yellow River Delta, China. Ecol Eng 35:1090-1103

Dahmani-Muller H, Van Oort F, Gelie B, Balabane M (2000) Strategies of heavy metal uptake by three plant species growing near a metal smelter. Environ Pollut 109:231-238

Dauvin JC (2008) Effects of heavy metal contamination on the macrobenthic fauna in estuaries: the case of the Seine estuary. Mar Pollut Bull 57:60-169

Deng H, Ye ZH, Wong MH (2004) Accumulation of lead, zinc, copper and cadmium by 12 wetland plant species thriving in metalcontaminated sites in China. Environ Pollut 132:29-40

Du Laing G, De Vos R, Vandecasteele B, Lesage E, Tack FMG, Verloo MG (2008) Effect of salinity on heavy metal mobility and availability in intertidal sediments of the Scheldt estuary. Estuar Coast Shelf Sci 77:589-602

Du Laing G, Rinklebe J, Vandecasteele B, Meers E, Tack FMG (2009) Trace metal behavior in estuarine and riverine floodplain soils and sediments: a review. Sci Total Environ 407:3972-3985

Duman F, Cicek M, Sezen G (2007) Seasonal changes of metal accumulation and distribution in common club rush (Schoenoplectus lacustris) and common reed (Phragmites australis). Ecotoxicology $16: 457-463$

Fan XM, Liu GH, Tang ZP, Sun LC (2010) Analysis on main contributions influences soil salinization of Yellow River Delta. J Soil Water Conserv 24(1):139-144

Flegal AR, Smith GJ, Gill GA, Sañudo-Wilhelmy S, Anderson LCD (1991) Dissolved trace element cycles in the San Francisco Bay estuary. Mar Chem 36:329-363

Fürtig K, Pavelic D, Brunold C, Brändle R (1999) Copper-and-iron induced injuries in roots and rhizomes of reed (Phragmites australis). Limnologica 29:60-63

Gambrell RP, Wiesepape JB, Patrick WH Jr, Duff MC (1991) The effects of $\mathrm{pH}$, redox, and salinity on metal release from a contaminated sediment. Water Air Soil Pollut 57(1):359-367

Guan YX, Liu GH, Wang JF (2001) Regionalization of salt-affected land for amelioration in the Yellow River delta based on GIS. Acta Geogr Sin 56:198-205

Hahne HCH, Kroontje W (1973) Significance of pH and chloride concentration on behavior of heavy metal pollutants: mercury(II), cadmium(II), zinc(II), and lead(II). J Environ Qual 2(4):444-450

Han N, Shao Q, Lu CM, Wang BS (2005) The leaf tonoplast V-H'ATPase activity of a $\mathrm{C}_{3}$ halophyte Suaeda salsa is enhanced by salt stress in a Ca-dependent mode. J Plant Physiol 162:267-274

Irabien MJ, Velasco F (1999) Heavy metals in Oka river sediments (Urdaibai National Biosphere Reserve, Northern Spain): lithogenic and anthropogenic effects. Environ Geol 37:54-63

Kabata-Pendias A, Pendias H (2001) Trace elements in soils and plants, 3rd edn. CRC Press, Boca Raton

Kähkönen MA, Pantsar-Kallio M, Manninen PKG (1997) Analysing heavy mental concentrations in the different parts of Elodea canadensis and surface sediment with PCA in two boreal lakes in southern Finland. Chemosphere 35(11):2645-2656

Li YF, Huang YL, Li SK (1991) A primarily analysis on the coastal physiognomy and deposition of the modern Yellow River Delta. Acta Oceanol Sin 13(5):662-671

Li X, Wai OW, Li YS, Coles BJ, Ramsey MH, Thornton I (2000) Heavy metal distribution in sediment profiles of the Pearl River estuary, South China. Appl Geochem 15(5):567-581

Li QS, Wu ZF, Chu B, Zhang N, Cai SS, Fang JH (2007) Heavy metals in coastal wetland sediments of the Pearl River Estuary, China. Environ Pollut 149(2):158-164

Lin S, Hsieh IJ, Huang KM, Wang CH (2002) Influence of the Yangtze River and grain size on the spatial variations of heavy metals and organic carbon in the East China Sea continental shelf sediments. Chem Geol 182(2):377-394
Liu Y, Ding TL, Wang BS (2006) Study on the leaf succulence of Suaeda salsa under differently natural saline environments. J Shandong Norm Univ (Nat Sci) 21(2):102-104

Liu XL, Zhang LB, You LP, Wu HF, Zhao JM et al (2011) Metabolomic study on the halophyte Suaeda salsa in the Yellow River Delta. Clean Soil Air Water 39(8):720-727

Masson M, Blanc G, Schäfer J (2006) Geochemical signals and source contributions to heavy metal $(\mathrm{Cd}, \mathrm{Zn}, \mathrm{Pb}, \mathrm{Cu})$ fluxes into the Gironde Estuary via its major tributaries. Sci Total Environ 370(1): 133-146

Mohammed AS, Kapri A, Goel R (2011) Heavy metal pollution: source, impact, and remedies. In Biomanagement of metal-contaminated soils. Springer Netherlands

Moran SB, Yeats PA, Balls PW (1996) On the role of colloids in trace metal solid-solution partitioning in continental shelf waters: a comparison of model results and field data. Cont Shelf Res 16:397-408

Mou XJ, Sun ZG, Wang LL, Dong HF (2010a) Characteristics of nitrogen accumulation and allocation of Suaeda salsa in different growth conditions of intertidal zone in Yellow River Estuary. Wetl Sci 8(1): $57-66$

Mou XJ, Sun ZG, Wang LL, Sun WL (2010b) Seasonal changes of potassium, calcium, and magnesium and their accumulation in different phenotype Suaeda salsa communities in a tidal flat of the Yellow River estuary. Acta Pratacult Sin 19(3):177-190

Mou XJ, Sun ZG, Wang LL, Wang CY (2011) Nitrogen cycle of a typical Suaeda salsa marsh ecosystem in the Yellow River estuary. J Environ Sci 23(6):958-967

Ngayila N, Botineau M, Baudu M, Basly JP (2009) Myriophyllum alterniflorum DC. Effect of low concentrations of copper and cadmium on somatic and photosynthetic endpoints: a chemometric approach. Ecol Indic 9:307-312

Pardue JH, Patrick Jr WH (1995) Changes in metal speciation following alteration of sediment redox status. Metal Contam Aquat Sediments: 169-185

Ramirez RG, Haenlein GFW, Núñez-González MA (2001) Seasonal variation of macro and trace mineral contents in 14 browse species that growth in northern Mexico. Small Rumin Res: 153-159

Ross SM (1994) Source and forms of potentially toxic metals in soil-plant systems. In: Ross SM (ed) Toxic metals in soil-plant system. John Wiley \& Sons, Chichester, pp 3-25

Ruan Y, Liu Y, Wang BS (2008) Study on the pigment accumulation and characteristics of photosynthesis of Suaeda salsa under different natural saline environments. J Shandong Norm Univ (Nat Sci) 23(1):115-117

Sajwan KS, Ornes WH, Youngblood TV, Alva AK (1996) Uptake of soil applied cadmium, nickel and selenium by bush beans. Water Air Soil Pollut 91:209-217

Salomons W, de Rooij NM, Kerdijk H, Bril J (1987) Sediments as a source for contaminants? Hydrobiologia 149:13-30

Samecka-Cymerman A, Kenpers AJ (2001) Concentrations of heavy metals and plant nutrients in water, sediments and aquatic macrophytes of anthropogenic lakes (former open cut brown coal mines) differing in stage of acidification. Sci Total Environ 281:87-98

Shewry PR, Peterson PJ (1974) The uptake and transport of chromium by barley seedlings (Hordeum vulgare L.). J Exp Bot 25(4):785-797

Simpson SL, Rosner J, Ellis J (2000) Competitive displacement reactions of cadmium, copper, and zinc added to a polluted, sulfidic estuarine sediment. Environ Toxicol Chem 19(8):1992-1999

Song HL, Sun ZG, Mou XJ, Zhao JY (2012) Salinity effect and seed priming treatments on the germination of Suaeda salsa in the tidal marsh of the Yellow River estuary. Afr J Biotechnol 11(31):79237933

State Oceanic Administration of China (2011) Ocean environmental quality communique of China in 2010. (http://www.coi.gov.cn/ gongbao/huanjing/201107/t20110729_17486.html) 
State Oceanic Administration of China (2012) Ocean environmental quality communique of China in 2011. (http://www.coi.gov.cn/ gongbao/huanjing/201207/t20120709_23185.html)

State Oceanic Administration of China (2013) Ocean environmental quality communique of China in 2012. (http://www.coi.gov.cn/ gongbao/huanjing/201304/t20130401_26428.html)

Sun ZG, Liu JS (2007) Nitrogen cycling of atmosphere-plant-soil system in the Calamagrostis angustifolia wetland in the Sanjiang Plain, Northeast China. J Environ Sci 19:986-995

Sun WL, Sun ZG, Mou XJ, Wang LL (2010) Distribution characteristics of phosphor and sulfur in different wetland soils of the Yellow River Delta. Bull Soil Water Conserv 30(4):104-109

Sun ZG, Mou XJ, Tian HQ, Song HL, Jiang HH, Zhao JY, Sun WL, Sun WG (2013a) Phosphorus biological cycle in the different Suaeda salsa marshes of the Yellow River estuary, China. Environ Earth Sci 69(8):2595-2608

Sun ZG, Mou XJ, Song HL, Jiang HH (2013b) Sulfur biological cycle of the different Suaeda salsa marshes in the intertidal zone of the Yellow River estuary, China. Ecol Eng 53:153-164

Sun WG, Gan ZT, Sun ZG, Li LL, Sun JK, Sun WL, Mou XJ, Wang LL (2013c) Spatial distribution characteristics of Fe and Mn contents in the new-born coastal marshes in the Yellow River estuary. Environm Sci 34(11):4411-4419

Tam NFY, Wong YS (1999) Mangrove soils in removing pollutants from municipal wastewater of different salinities. J Environ Qual 28(2): 556-564

Thiesen MO, Blincoe C (1988) Isolation and partial characterization of nickel complexes in higher plants. Biol Trace Elem Res 16:239-251

Tian JY, Wang XF, Cai XJ (2005) Protection and restoration technique of wetland ecosystem in Yellow River Delta. China Ocean University Press, Qingdao

Tiffin LO (1971) Translocation of nickel xylem exudate of plants. Plant Physiol 48:273-277

Wang CQ, Zhao JQ, Chen M, Wang BS (2006) Identification of betacyanin and effects of environment factors on its accumulation in halophyte Suaeda salsa. J Plant Physiol Mol Biol 32:195-201
Wang L, Yue XX, Wang BS (2008) The comparative study on POD in the leaves of two different phenotype of Suaeda salsa L. grown under different natural conditions. J Shandong Norm Univ (Nat Sci) 23(4): $103-105$

Williams TP, Bubb JM, Lester JN (1994) Metal accumulation within saltmarsh environment: a review. Mar Pollut Bull 28: $277-290$

Windham L, Weis JS, Weis P (2003) Uptake and distribution of metals in two dominant salt marsh macrophytes, Spartina alterniflora (cordgrass) and Phragmites australis (common reed). Estuar Coast Shelf Sci 56:63-72

Wu HF, Liu XL, Zhao JM, Yu JB, Pang QY, Feng JH (2012) Toxicological effects of environmentally relevant lead and zinc in halophyte Suaeda salsa by NMR-based metabolomics. Ecotoxicology 21:2363-2371

Xiao R, Ba J, Huang L, Zhang H, Cui B, Liu X (2013) Distribution and pollution, toxicity and risk assessment of heavy metals in sediments from urban and rural rivers of the Pearl River delta in southern China. Ecotoxicology 22(10): $1564-1575$

Xu XG, Guo HH, Chen XL, Lin HP, Du QL (2002) A multi-scale study on land use and land cover quality change: the case of the Yellow River Delta in China. GeoJournal 56(3):177-183

Yang HJ, Shen ZM, Zhu SH, Wang WH (2008) Heavy metals in wetland plants and soil of Lake Taihu, China. Environ Toxicol Chem 27(1): $38-42$

Zhang LP, Ye X, Feng H, Jing YH, Yang TO, Liang RY, Gao CT, Chen WQ (2007) Heavy metal contamination in western Xiamen Bay sediments and its vicinity, China. Mar Pollut Bull 54:974-982

Zhang HG, Cui BS, Xiao R, Zhao H (2010) Heavy metals in water, soils and plants in riparian wetlands in the Pearl River Estuary, South China. Proc Environ Sci 2:1344-1354

Zhang HG, Cui BS, Zhang KJ (2011) Heavy metal distribution of natural and reclaimed tidal riparian wetlands in south estuary, China. J Environ Sci 23(2):1937-1946 